\title{
Consumer's perception and preference on fresh vegetables (Carrots, Egg plants, Okra and Pepper) coated with wax of shea butter (Vitellaria paradoxa) oil
}

\author{
Tsado, E. K. ${ }^{1 *}$, Salaudeen, M. T. ${ }^{1}$, Adesina, O. A. ${ }^{1}$, Ekpa, D. ${ }^{2}$ and Muhammed, K. A. ${ }^{2}$ \\ 1Department of Crop Production, Federal University of Technology Minna, Niger State, Nigeria. \\ ${ }^{2}$ Department of Crop Production and Protection, Federal University Dutsin-ma, Katsina State, Nigeria. \\ *Corresponding author. Email: ektsado@yahoo.co.uk
}

Copyright @ 2018 Tsado et al. This article remains permanently open access under the terms of the Creative Commons Attribution License 4.0, which permits unrestricted use, distribution, and reproduction in any medium, provided the original work is properly cited.

Received 21st March, 2018; Accepted 25th April, 2018

\begin{abstract}
Carrot, garden eggplant, okra and pepper were coated with melted shea butter oil by robbing it around the vegetables and then stored for a period of twenty days. The coated fruits took longer time to deteriorate when compared with the uncoated fruits signifying that coated vegetables fruits with edible coating material increases the shelf life and storage longevity. This fact has led the consumers to accept that shea butter is a very good edible coating material that can extend any food material. Some consumers accepted shea butter with mixed feelings. Reasons for their mixed feelings are that some do not take shea butter; they prefer vegetables and fruits in their natural form or processed. The findings from the study showed significant difference in the number of people preferring the freshly coated vegetables from uncoated vegetables and also the differences observed between the vegetables.
\end{abstract}

Key words: Coating, coated vegetables, shea butter, shelf life, vegetables.

\section{INTRODUCTION}

The need and demand for processed fruits and vegetables in markets of developing and developed economies is growing drastically due to changes in new way of life, serious health concerns or improved power of purchase (Acuff, 1993; McHugh and Senesi, 2000; Jiang and Joyce, 2002). Fruits and vegetables are highly perishable commodities that require to be handle with much care to minimize losses. Post-harvest losses due to inadequate storage and handling are enormous and can range from 20 to 50 percent in developing countries (Kader, 1992).

The varieties of sustenance utilization continue fluctuating constantly, subject to propensities for individuals or the accessibility of specific nourishments at various seasons (Greenwood, 1998). In view of the inclining ways of life customers invest little energy for the readiness of their dinner.

A few strategies have been being used for keeping up the nature of produces. Chilling strategy, high relative moistness, controlled barometrical and adjusted palatable film bundling, engineered film bundling, and so on are great cases of systems that have exuded after some time and are been utilized as a part of nourishment's stockpiling. These have had their benefits and negative marks on the utilization (Risch, 2002).

Shea butter is a vegetable fat extracted from the kernel of the shea tree (Vitellaria paradoxa), a tree belongs to the group of Sapotaceae. The tree is the fundamental indigenous oil producing wild plant openly cultivated in Africa (Honfo et al., 2012). The tree grows wild and covers about $5000 \mathrm{~km}$ of the savanna belt (Masters et al., 2004), including West African nations like Nigeria, Senegal, Mali, Burkina Faso, Togo, Ghana, Benin, Niger, Cameroon, Uganda, Sudan and Ethiopia (Hee, 2011). Four of these nations represent around 600,000 MT (about $80 \%$ ) of world shea nut production. The countries include; Nigeria (370.000 MT), Mali (85.000 MT), Burkina Faso (70.000 MT) and Ghana (61.000 MT) (Karen, 2005). Among these nations, Ghana and Burkina Faso are the principle shea nut exporters (Hee, 2011). Nigeria produces about $50 \%$ of the world shea nut production, yet has a tendency to 
expend the majority of its shea nuts locally (Karen, 2005).

Nigeria is home to different fruits and vegetables but are only available in season. This is attributed to poor harvest handling, post-harvest diseases and lack of preservation method. It is a known fact that fruits are perishable and it takes considerable time for a fruit produce to reach the table of the consumer. During the time-consuming process involved in handling, storage, and transportation, products start to dehydrate, deteriorate, and lose appearance, flavor and nutritional value. Because of its shorter shelf life, fruits on the table of consumers usually last for few days. If no special protection is provided, the fruits produced will quickly run into deterioration and as such reducing the shelf life and its availability.

Methods of preservation of fruits and vegetables during storage and marketing are generally based on refrigeration and use of chemicals (Smith and Stow, 1984; Smith et al., 1987). So, chemical storage method and chilling storage method are not economically feasible in most developing countries (Smith et al., 1987; Li and Yu, 2000). Techniques used in developed countries include the use of edible coatings and organic chemical treatments mainly for the greater quality of fresh fruits and vegetables. Edible coating is a thin layer of edible material enrobed on fruit surface as an addition or a replacement for the natural protective waxy coating (Risch, 2002). Shear butter coating which is produced cheaply and readily available was used to enrobe the fruits. The fruits used in the study are; carrot (Daucus carota) from the family of Umbelliferae, garden egg (Solanum melongena) from the family of Solanaceae, okra (Abelmoschus esculentus) from the family of Malvaceae and pepper (Capsicon annum) from the family of Solanaceae.

Works in the past have shown that edible coatings not only increase the market opportunity for traders but are equally essential in extending the shelf life of the produce. The work of Bett-Garber et al. (2001) has shown that consumer acceptance of coated or uncoated fruits and vegetables have been accepted with mixed feelings. Surveys conducted on consumer perception of whole fruits and vegetables have shown mixed feelings. Few have, however, been reported on consumer's awareness of coated fruits and vegetables in developing countries like Nigeria. Thus, the main objective of this study is to evaluate consumers' acceptance and preference of the edible coated fruits (carrot, garden egg, pepper, and okra). The specific objectives are to:

1. compare consumers' perception and preference among treated and untreated fresh fruit produce over time.

2. evaluate consumers' preference among the four fruits; carrot, garden eggs, pepper, and okra.

3. determine the effect of demographic characteristics on the consumers' perception of the treated fruits.

4. evaluating factors affecting consumers' decision to select fruit.
The null hypothesis for the study was that there was no difference in the shea butter oil was used for vegetables and how consumers will accept the product.

\section{MATERIALS AND METHODS}

The research work was carried out in the School of Agriculture and Agricultural Technology Laboratory of the Federal University of Technology Minna, Niger State.

\section{Source of experimental material}

Carrot, garden egg, okra and pepper were obtained from fruit market along Mobil, Chanchaga Local Government Area of Niger State. Shear butter oil made from the fruit of shear (Vitellaria paradoxum) tree and cotton board was obtained from Bosso market, Chanchaga Local Government Area of Niger State.

\section{Experimental procedure}

Fifty of each of the fruits was coated with shea butter oil which was melted under heat energy (sun), while ten of each of the four fruits were left uncoated as the control and they were stored for a period of twenty days. Pictures of the fruits were taken at day 0 , day 5 , day 10 , day 15 and day 20 respectively (Plates 1 to 4 ). Thereafter survey was carried out to determine the quality and rate of deterioration. Samples of the coated fruit and pictures were taken to respondents alongside with questionnaires on every fifth day.

\section{The survey procedure}

An investigative survey research approach (ISRA) was used where a set of structured questionnaires was distributed to consumers. Demographic data of the respondents (characteristics such as age, gender, marital status, level of education attained, household income and family size) on their acceptance of coated fruits were gathered. Also included was their choice of the four fruits based on the market outlet, factors affecting their decision to purchase fruits and factors influencing their purchase behavior. The next group of questions tried to address factors affecting consumers' perception on the rate of deterioration. Another set of questions was aimed at determining the factors affecting consumers purchase behavior. The questionnaires were administered in the school premises. An attempt was made to get all completed questionnaires returned within two days of administration. People above 20 years of age were selected as the respondents in order to obtain good distribution of all responsible age groups of people for this 


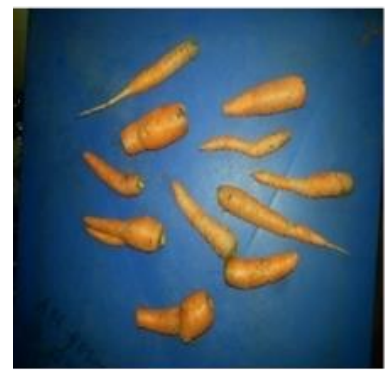

Day 0

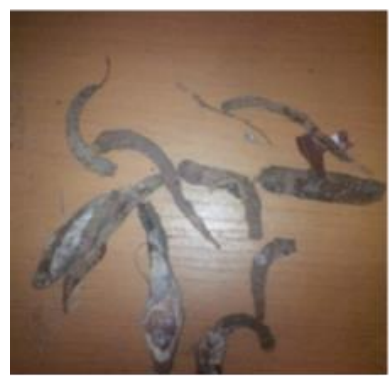

Day 15

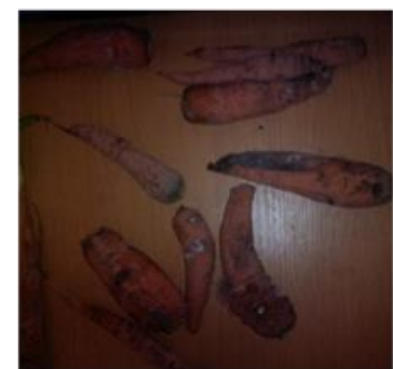

Day 5

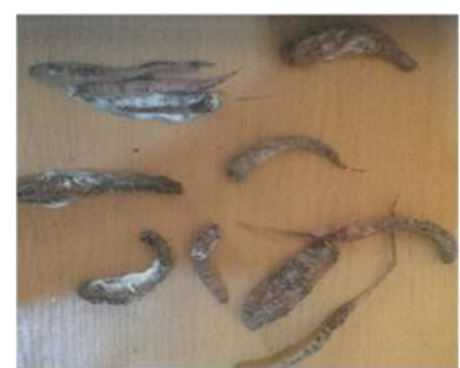

Day 20

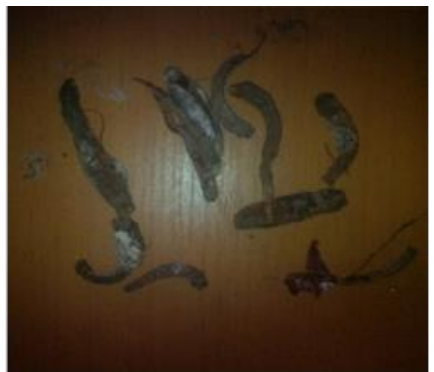

Day 10

Plate 1. Showing rate of deterioration of the uncoated carrot.

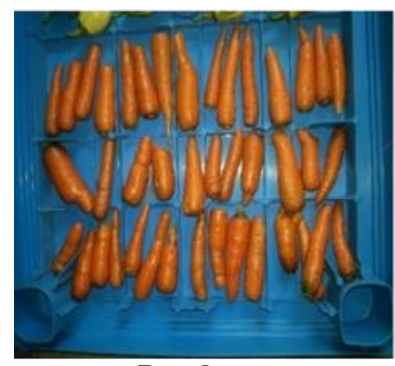

Day 0

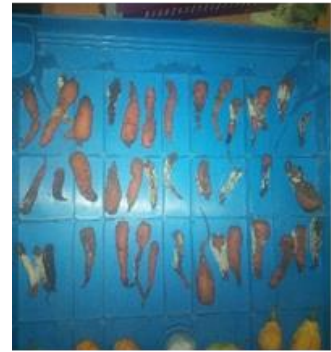

Day 15

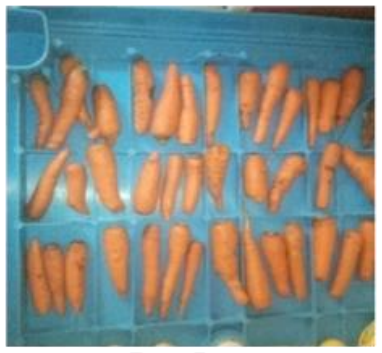

Day 5

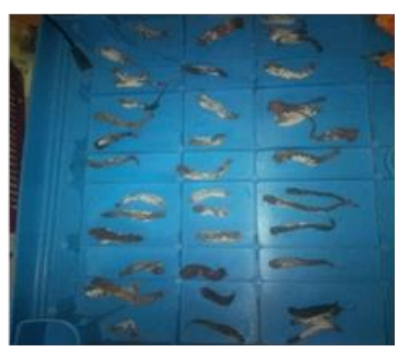

Day 20

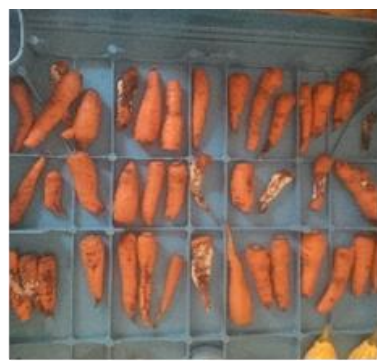

Day 10

Plate 2. Showing rate of deterioration of the coated carrot.

study. The questions were coded accordingly for proper data analysis.

\section{Data analysis}

All the collected data were subjected to descriptive statistics, while frequency of occurrences and percentages of the means were used to describe the responses.

\section{RESULTS}

The results of the study are presented graphically. There was significant difference in the rate of deterioration between the coated fruits and the control (uncoated). The four fruits (carrot, garden eggplant, okra and pepper) that were coated with shea butter oil show longevity in the number days before their spoilage became obvious in 


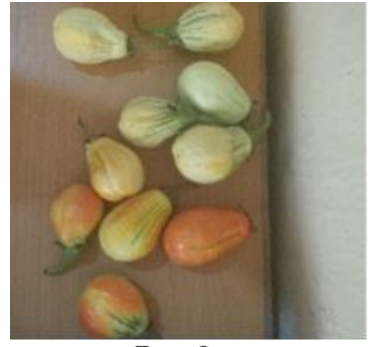

Day 0

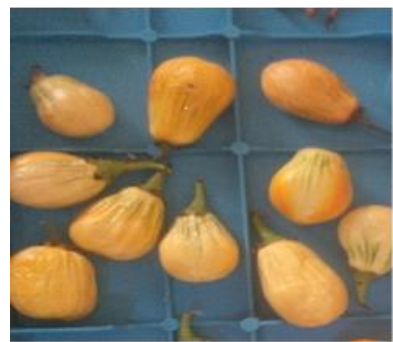

Day 15

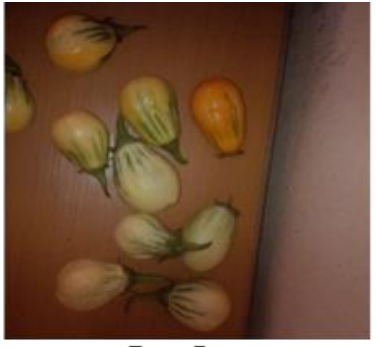

Day 5

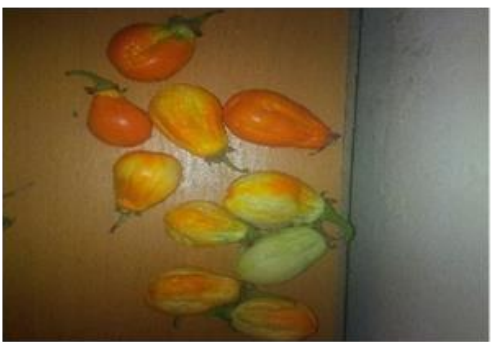

Day 20

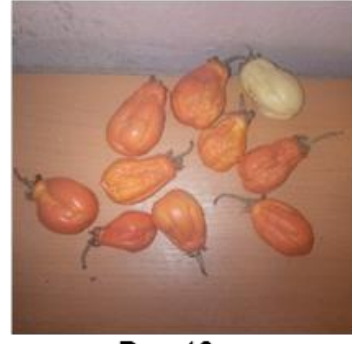

Day 10

Plate 3. Showing rate of deterioration between uncoated garden egg.

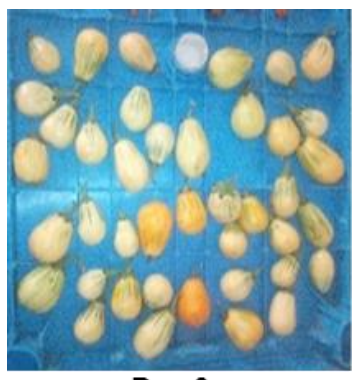

Day 0

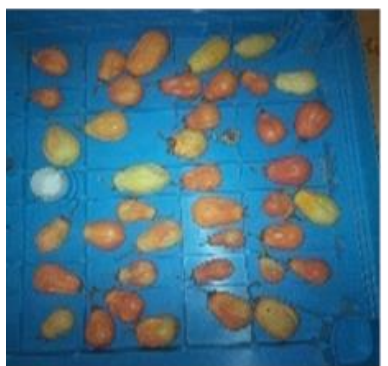

Day 15

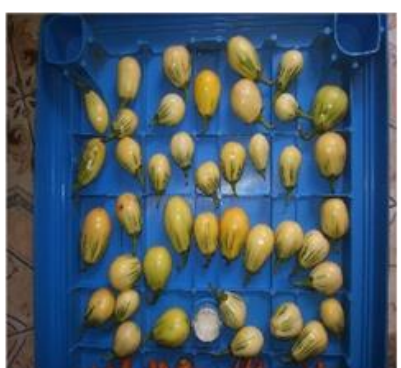

Day 5

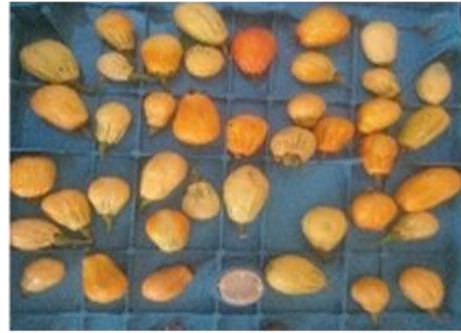

Day 20

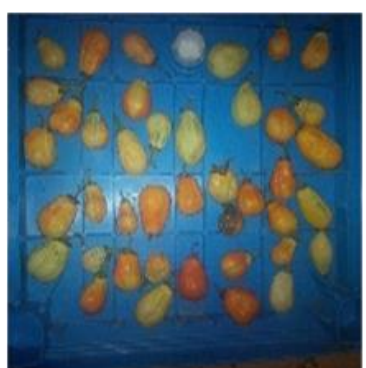

Day 10

Plate 4. Showing rate of deterioration of the coated garden egg.

comparison to those that were taken as the control.

\section{Rate of deterioration between coated and uncoated fruits}

\section{Day five result of the coated and uncoated fruits}

Day 5 was the first time the coated fruits were compared with the uncoated fruits. It was seen that the rate of deterioration was slow in the coated fruit whereas it was fast in the uncoated fruits. Coated fruits indicated with blue color showing much resistance to deterioration (Figure 1).

\section{Day ten result of the coated and uncoated fruits}

At day 10 , the coated fruits were still observed to deteriorate slowly when compared with the uncoated fruits 


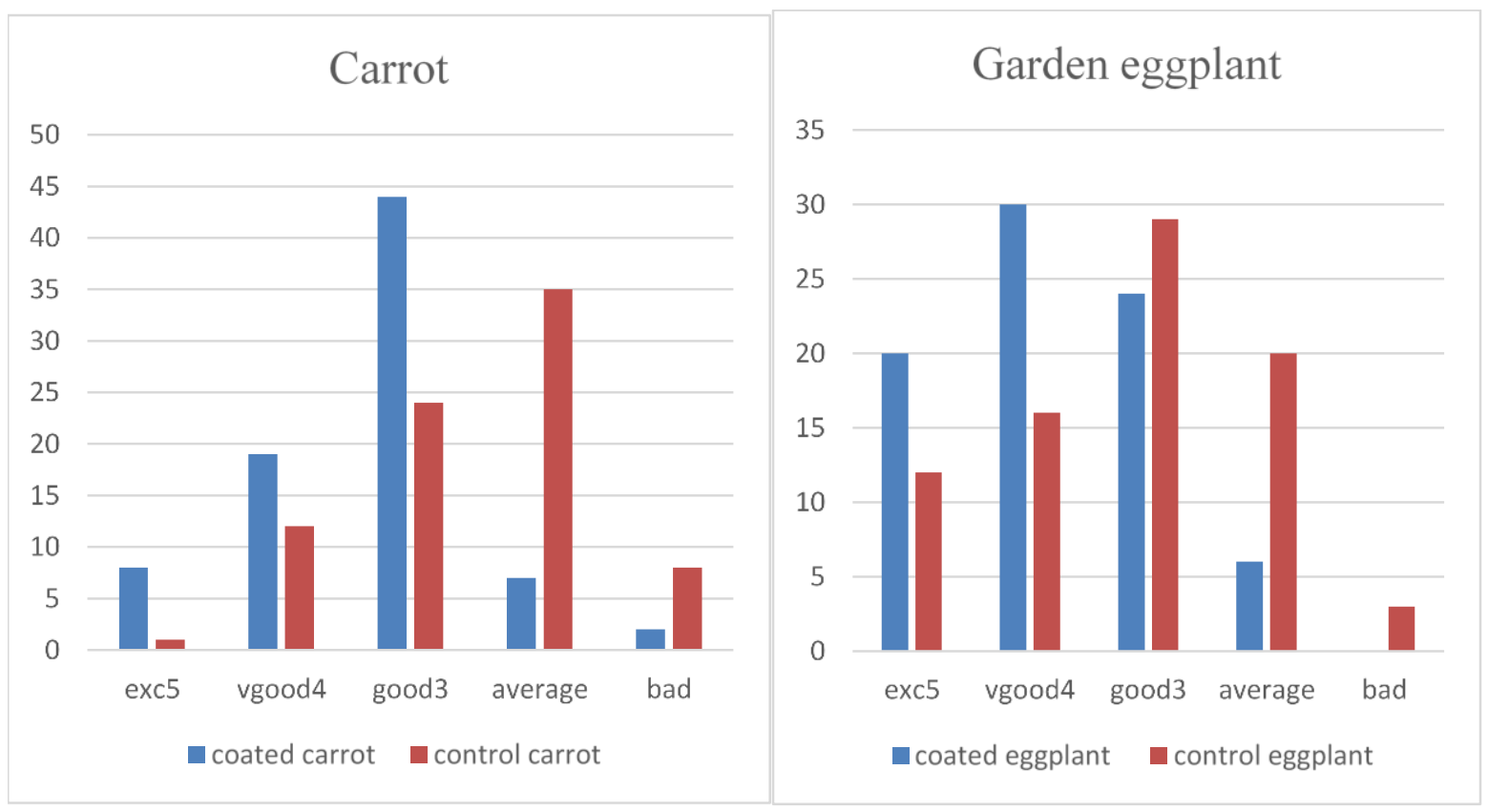

Figure 1a. Rate of deterioration at day five (5) for coated and uncoated fruits. (carrot and garden eggplant).

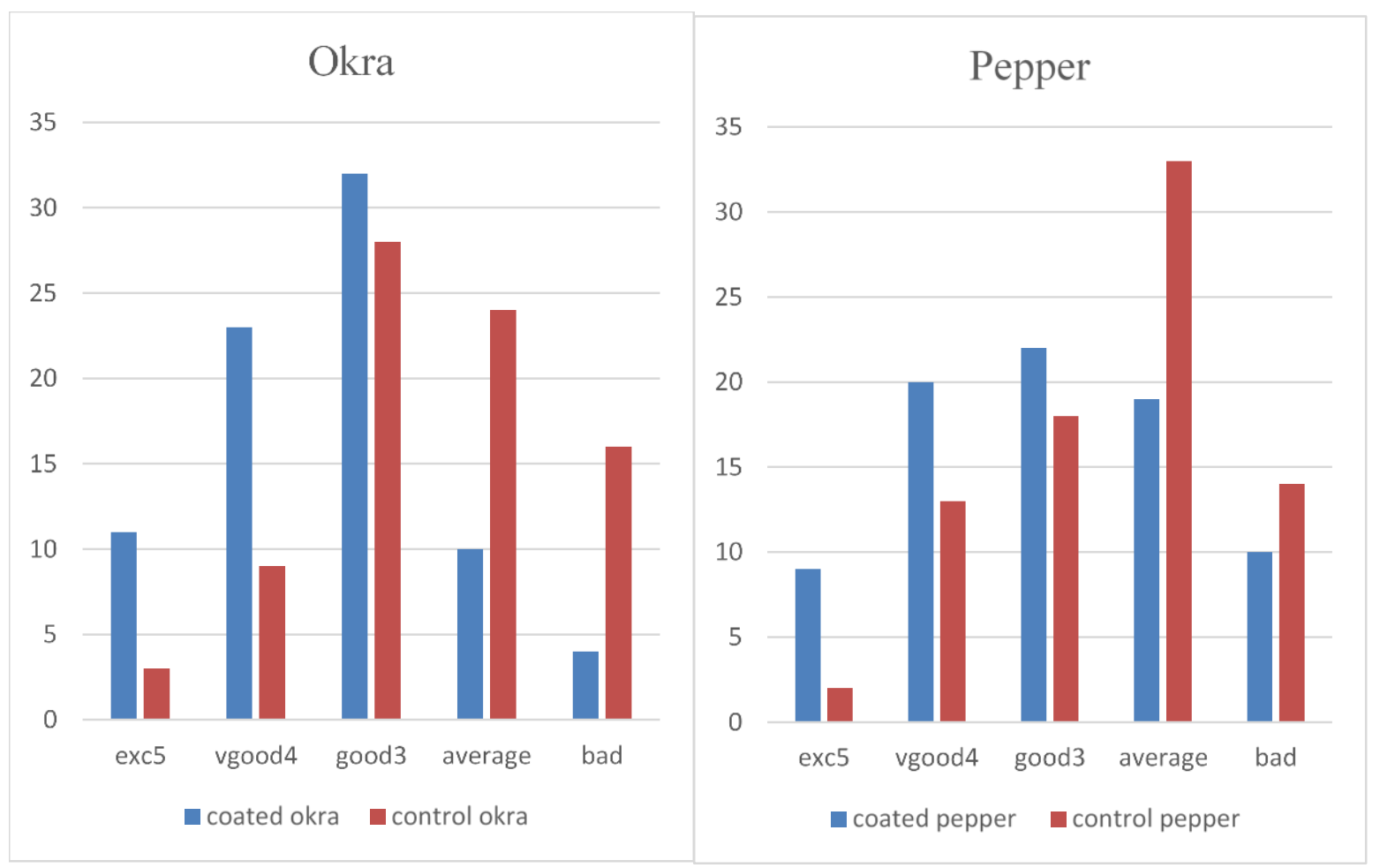

Figure 1b. Rate of deterioration at day five (5) for coated and uncoated fruits. (Okra and Pepper).

and at this point, the number of people choosing bad for the uncoated rose rapidly. No body chose excellent for any fruit except for garden eggplant (Figure 2).
Day fifteen result of the coated and uncoated fruits

At day 15 , uncoated fruit was worse. Though, none of them 


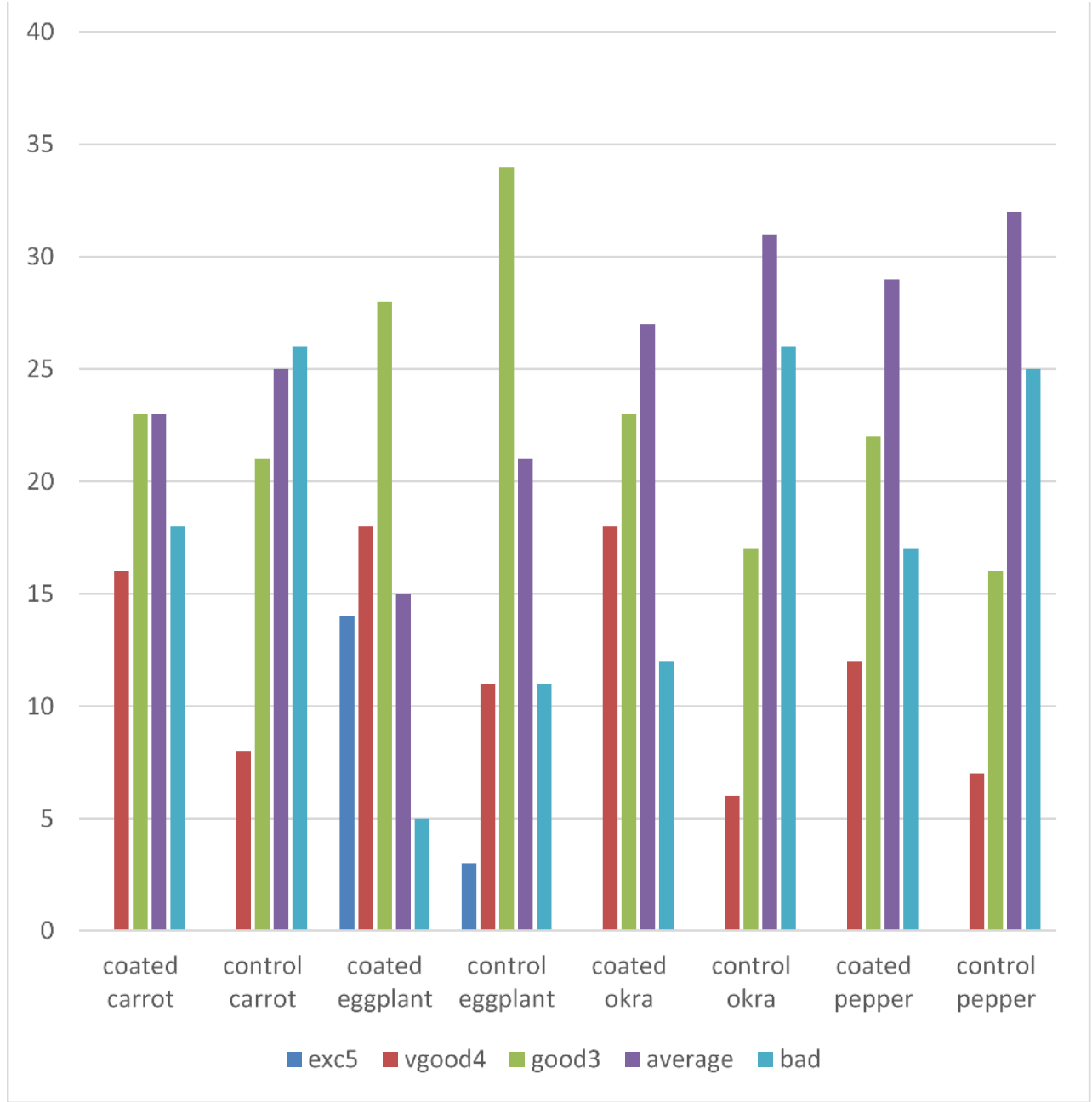

Figure 2. Rate of deterioration at day ten (10) for coated and uncoated fruits.

was chosen to be excellent. The number of people that recorded bad for the coated fruit were few compared to the uncoated which was greater (Figure 3).

\section{Day twenty result of the coated and uncoated fruits}

At day 20 , deterioration was so obvious in the uncoated compared to the coated. Garden egg stands out among the four fruits which show more resistance than the other fruits. Even at day 20, 'Good' was recorded for the coated garden egg, at this point other fruits were not; thus making consumers to choose garden eggplant as number one fruit from the study (Figure 4). Effect of demographic characteristics on the
consumers' perception of the treated fruits

\section{Age}

When the age of the respondents were ranged between 20 to 25,26 to 30,31 to 35 and 36 to 40 , people within the age of 26 to 30 prefer the coated fruits followed by the people within the age range of 36 to 40 and 31 to 35 . The least was 21 to 25 years of age. Probably because youths from here prefer the fruits mostly in their natural form. Though, only $15.15 \%$ of their populations prefer the coated fruits (Figure 5).

\section{Gender}

The male gender prefers the coated fruits when compared with the female gender. About $67.92 \%$ of male population prefers edible coated fruits while $32.08 \%$ of the male population prefers the fruit in its natural form. Also, about $40 \%$ of the female population preferred the coated and $60 \%$ of the female prefer the fruit in its natural form. Thus, giving the male gender preference over the female gender (Figure 6).

\section{Marital status}

About $61.54 \%$ of the population of married people prefer 


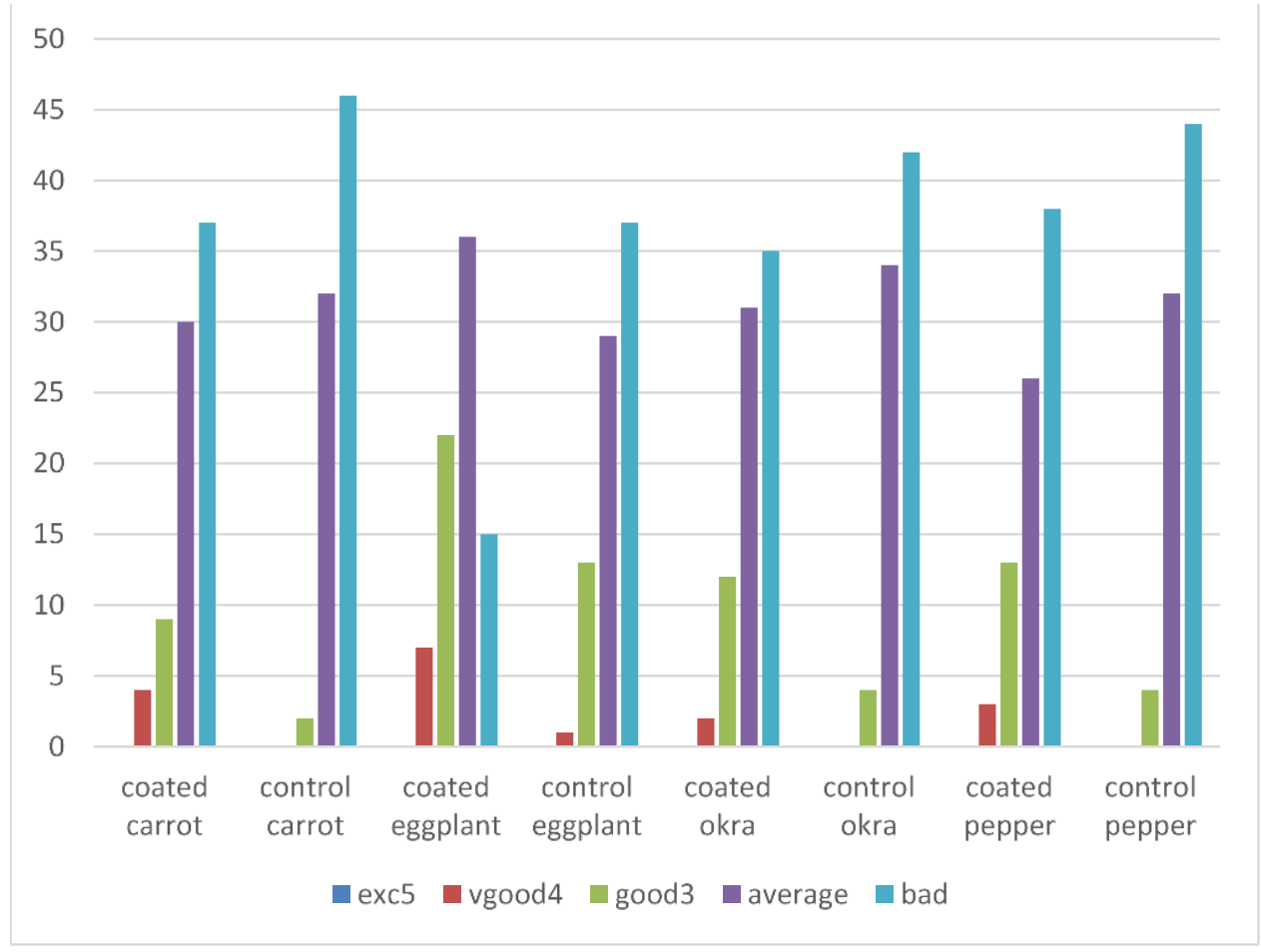

Figure 3. Rate of deterioration at day fifteen (15) for coated and uncoated fruits.

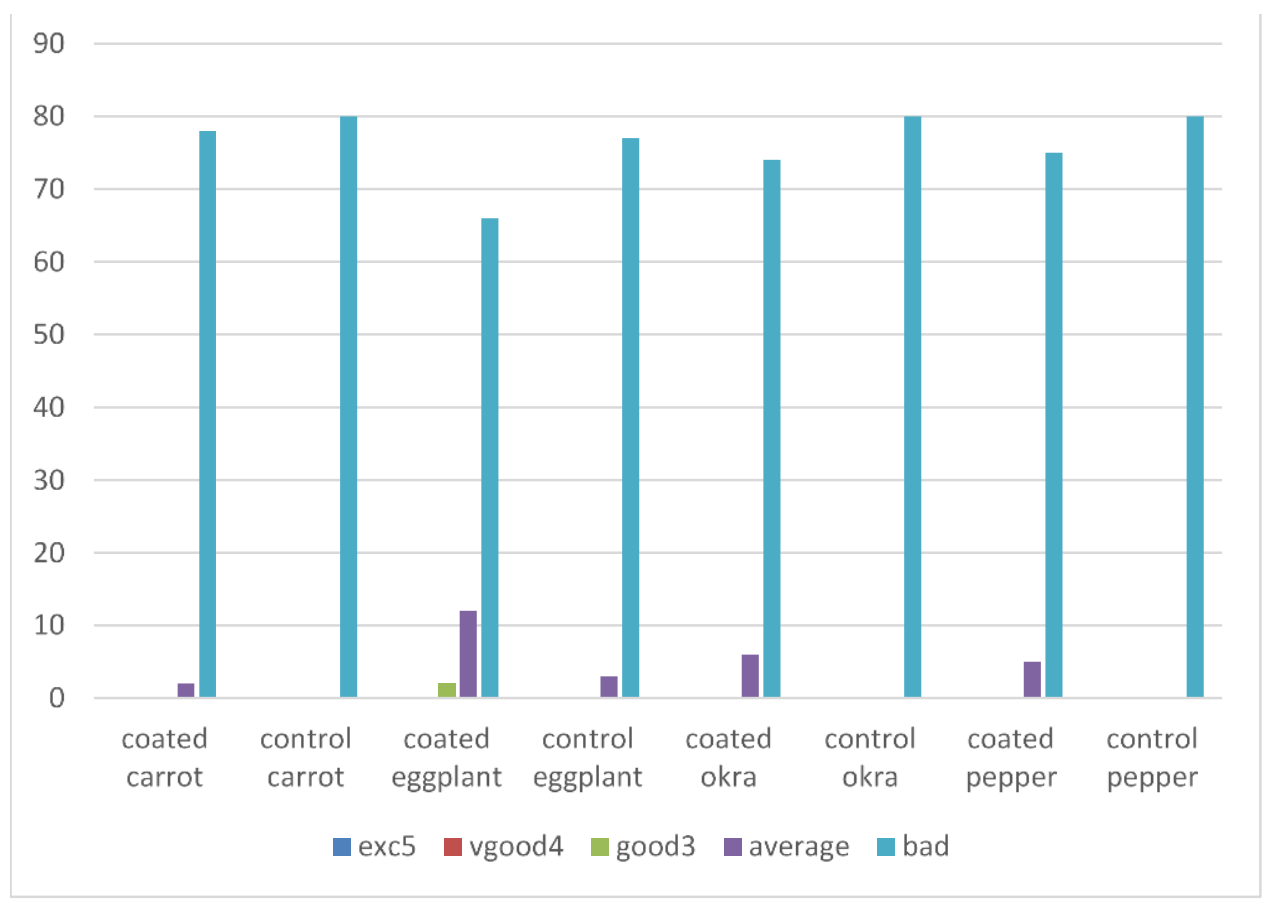

Figure 4. Rate of deterioration at day twenty (20) for coated and uncoated fruits.

edible coated fruits while $38.46 \%$ did not prefer the uncoated fruit. This was followed by $60.42 \%$ population of the singles that preferred the coated fruit. The widow and divorced have the smallest population of 2 and 3 respectively, and none prefer the coated fruit as they prefer the fruits in their natural form. Thus, the married people 


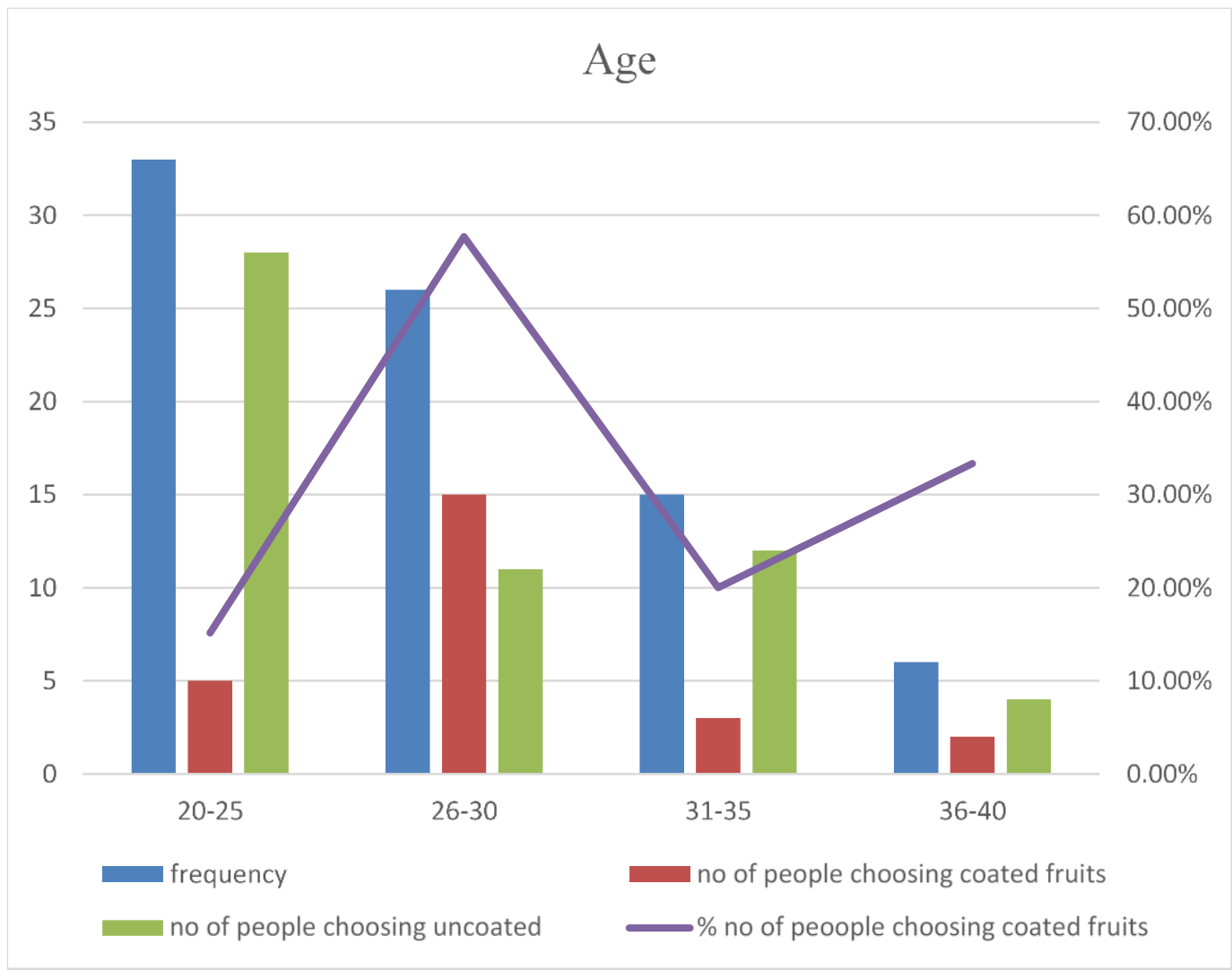

Figure 5. Effect of demographic characteristics (age) on the consumers' perception of the treated fruits.

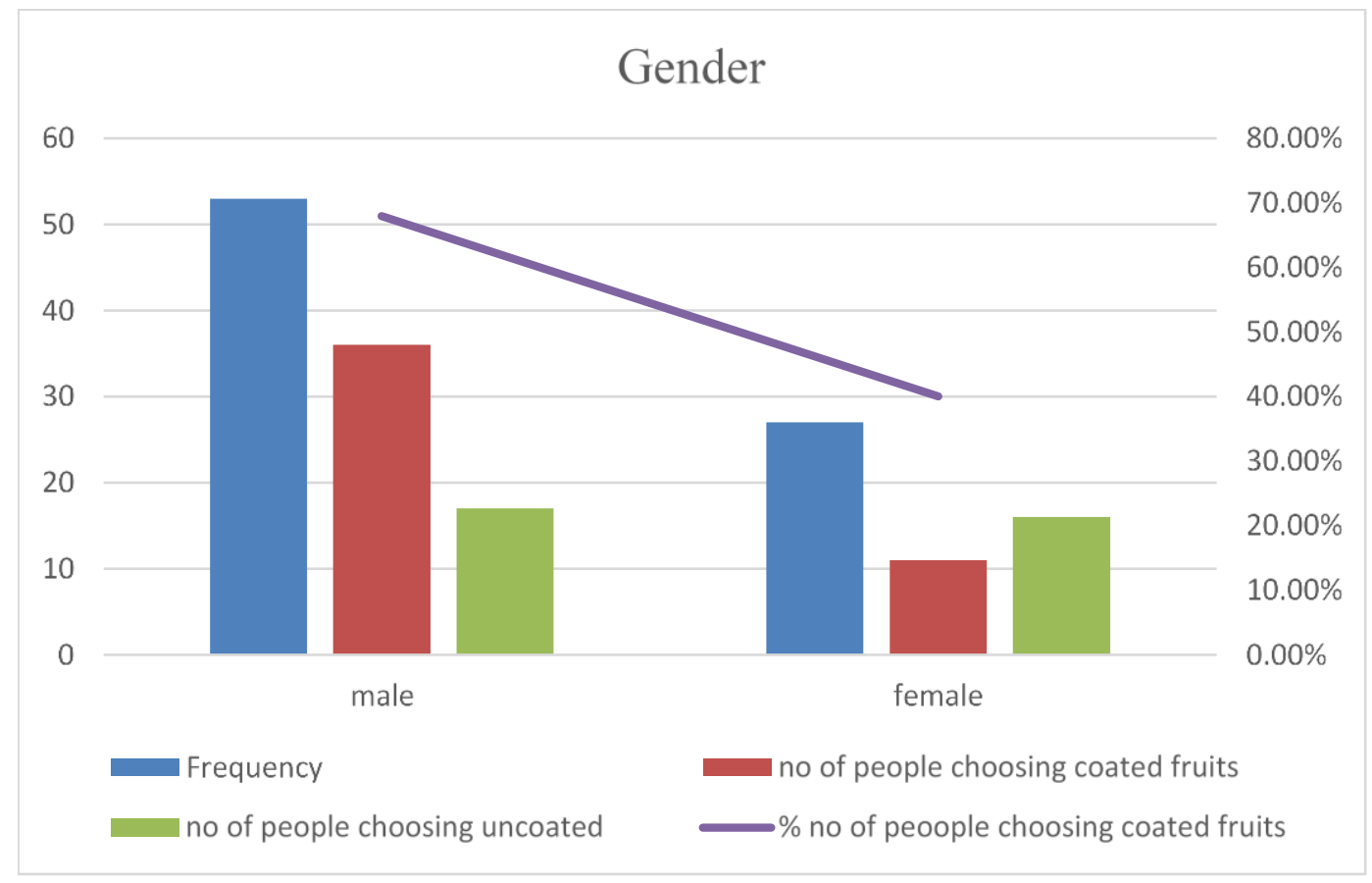

Figure 6. Effect of demographic characteristics (gender) on the consumers' perception of the treated fruits. 


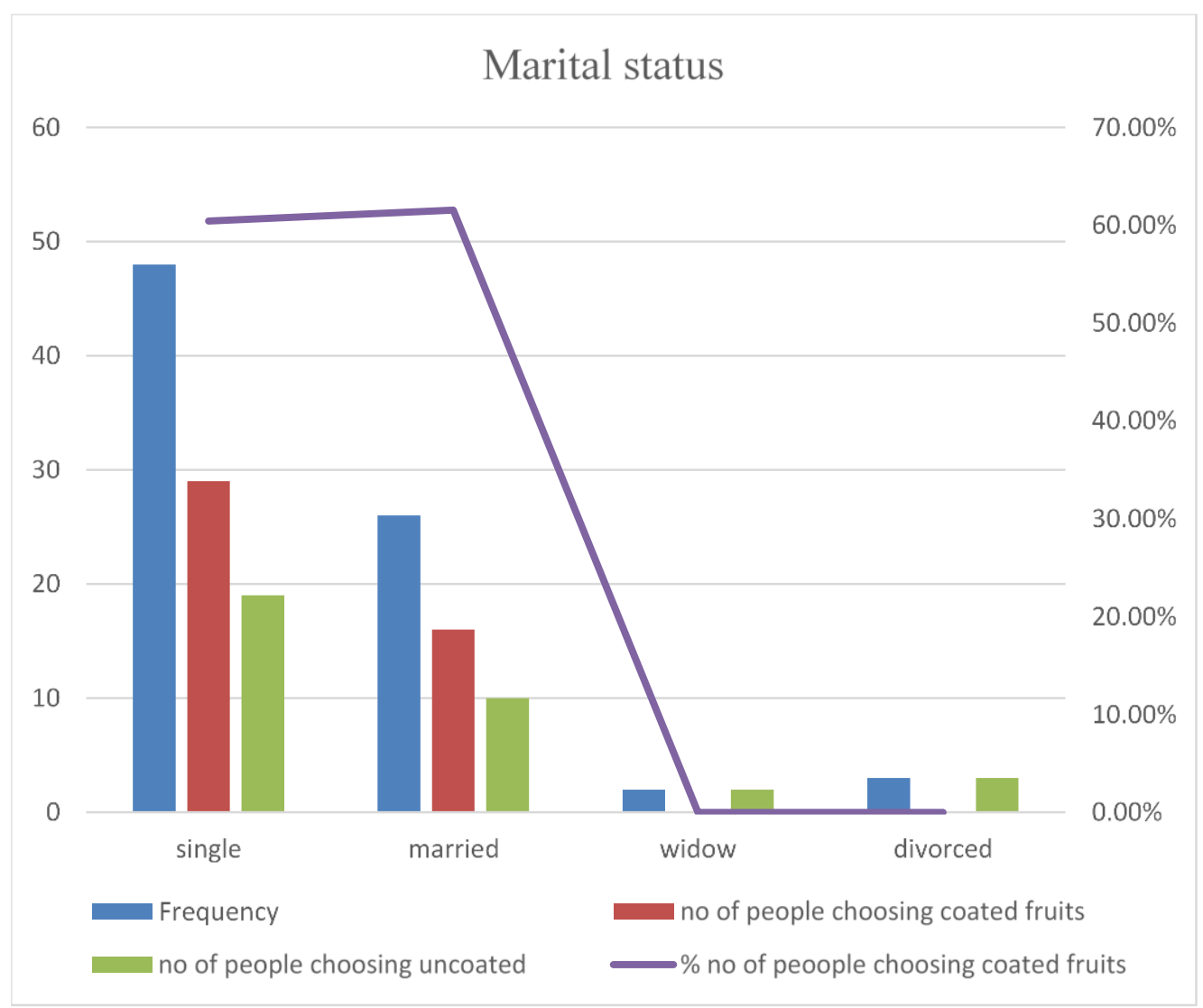

Figure 7. Effect of demographic characteristics (marital status) on the consumers' perception of the treated fruits.

prefer the coated fruits followed by the singles (Figure 7).

\section{Level of education}

$100 \%$ of the population of the Quranic chose coated fruits. Also, $75 \%$ of the population of the people above degree and adult education both chose coated fruit while $35 \%$ of their population prefers the uncoated fruits. This was followed by $37.04 \%$ of tertiary population that preferred the coated fruits. The least came from primary, secondary and none as none of them chose coated fruits (Figure 8).

\section{Income}

People whose income is $<\mathrm{N} 15,000$ prefer coated fruits with $65.22 \%$ of their population and $34.78 \%$ prefer the uncoated. This was followed by $54.55 \%$ of the population whose income is $>\mathrm{N} 45,000$ and $45.45 \%$ of their population prefer the uncoated fruits. Only $44.44 \%$ of the people whose income is between N30,000 and N45,000 prefer the coated fruit. The least came from between N15,000 and $\mathrm{N} 30,000$ with $42.86 \%$ of their population preferred the coated fruit (Figure 9).

\section{Factors affecting consumers' decision to select fruit}

Among the factors affecting consumers' decision to purchase fruits, quality of produce followed by fruits' availability were the most factors of determination (Figure 10). This indicates the fruit preservation and storage are of necessity. Coating fruits is a method which improves fruits produce and availability over time.

\section{DISCUSSION}

From the study, the rate of deterioration of the coated fruits was very slow which was significantly different from the uncoated fruits. Even though consumers have mixed feelings because some of them do not know about shear butter to be edible and some thought it is only used for rubbing hair and skin. The shea butter create a barrier between the fruits and the atmosphere and as such extending the shelf life of food material being enrobed. This is in line with the work of Bett-Garber et al. (2001) who reported mixed feelings among the consumer acceptance of products, especially coated or uncoated fruits and vegetables. Surveys conducted on consumer perception of whole fruits and vegetables have shown mixed feelings, 


\section{Level of education}

60

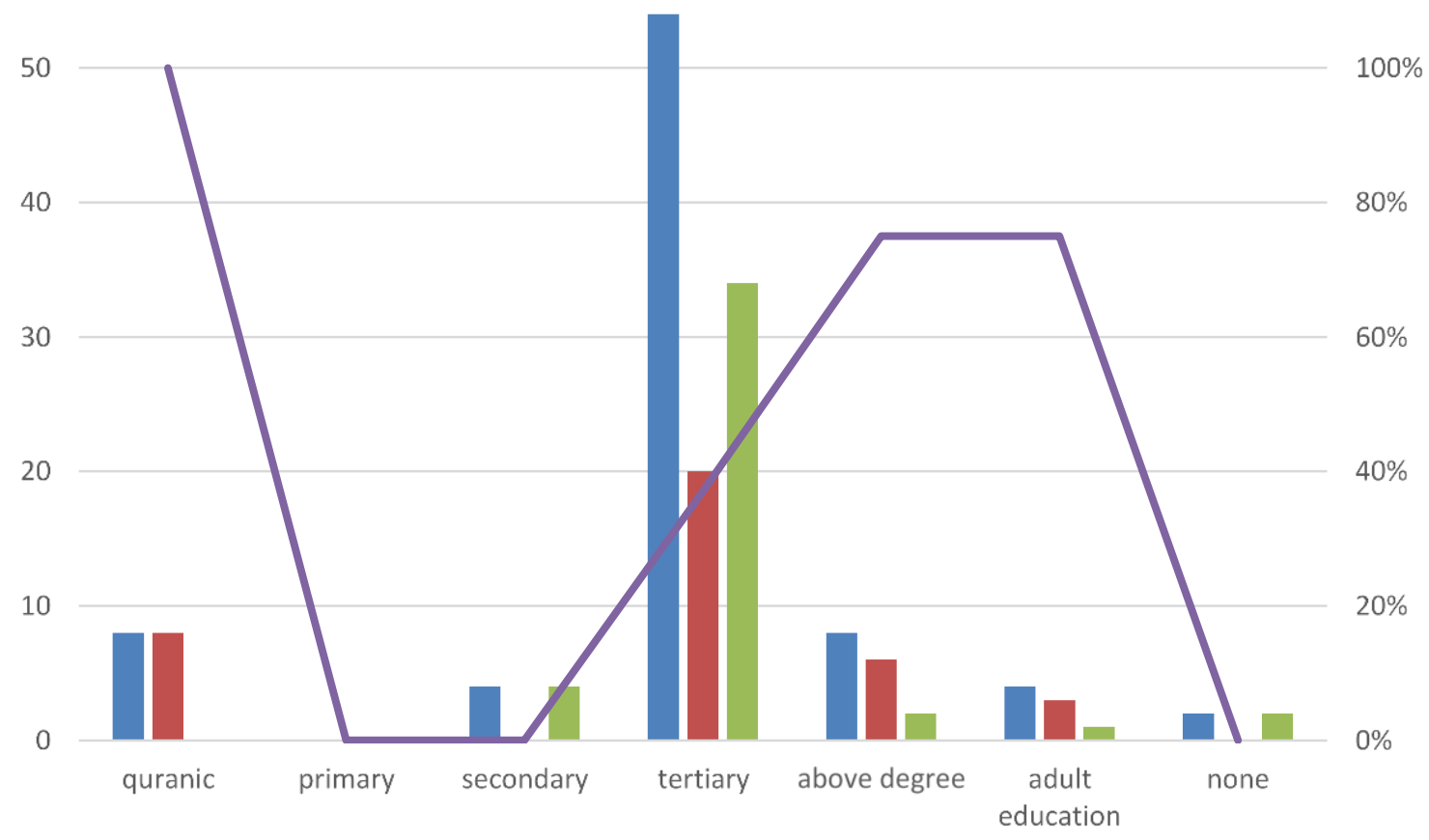

frequency

no of people choosing coated fruits

no of people choosing uncoated

$\%$ no of peoople choosing coated fruits

Figure 8. Effect of demographic characteristics (level of education) on the consumers' perception of the treated fruits.

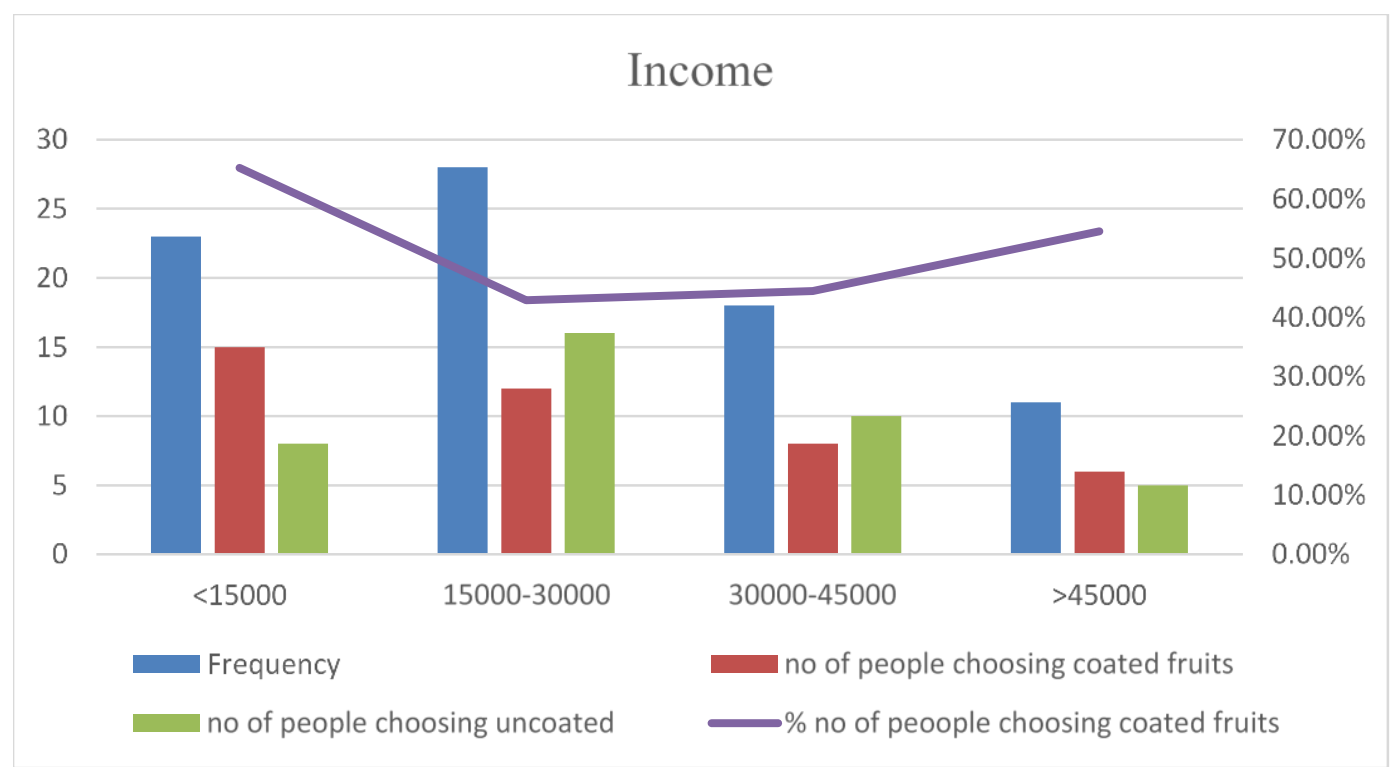

Figure 9. Effect of demographic characteristics (income) on the consumers' perception of the treated fruits. 


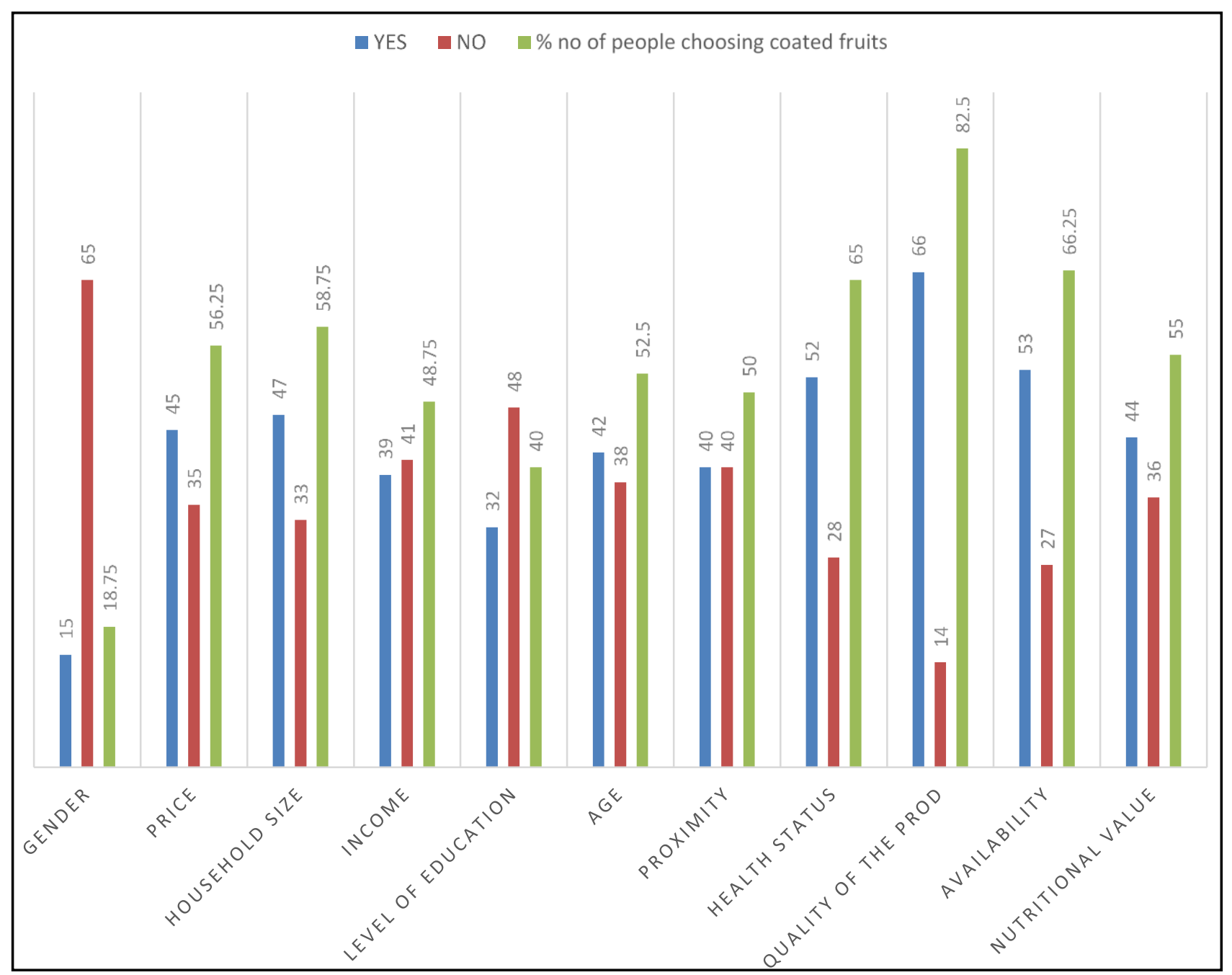

Figure 10. Factors affecting consumer's decision to select fruit.

few have however, been reported on consumer's awareness of coated fruits and vegetables in developing countries like Nigeria. It is in this light that knowing consumers' perception towards fresh fruits and vegetables coated with edible material would help the food industry understand consumer attitudes and market demands in developing economies like that of Nigeria where the population is also on the increase.

Studies have shown that ripening can be retarded, colour changes can be delayed, water loss and decay can be reduced, and appearance can be improved by using a simple and environmentally friendly technology, edible coating (Park et al., 1994a, b; Baldwin, 1995). This is true when spoilage was obvious in the uncoated after some days; colour was lost and desiccation was not reduced. Whereas the rate in coated fruits was retarded, colour changes were delayed and desiccation was reduced.

In this study, garden eggplant among the four fruits was excellent and was seen at every point to be better than the other fruits. Even at the final day the coated garden eggplant was chosen to be 'good' by some consumers of which no fruit have received such. It is in this respect that the consumers prefer garden eggplant.

Among the factors affecting consumers' decision to purchase fruits, quality of produce followed by fruits availability were the most factor of determination. Which conform to the reasons why it is necessary for fruit preservation and storage. Coating fruits is a method which improves fruits produce and availability over time.

\section{Conclusion and recommendation}

In conclusion, it was found that shear butter is a very good edible coating material which is readily available and can be used to coat fruits and vegetables in order to increase its period of storage and market availability. It is therefore recommended to the food industry and marketers to use shear butter instead of chemicals for fresh produce preservation. Fresh fruits and vegetables coated with 
edible material would help the food industry understand consumer attitudes and market demands in developing economies like that of Nigeria.

\section{CONFLICT OF INTEREST}

The authors declare that they have no conflict of interest.

\section{REFERENCES}

Acuff, G. (1993). Fresh-cut: New market for fruit? Fruit Grower. Pp. 16-17.

Baldwin, E. A, Nisperos-Carriedo, M. O., \& Baker, R. A. (1995). Use of edible coatings to preserve quality of lightly (and slightly) processed products. Critical Reviews in Food Science and Nutrition. 35(6), 509-52.

Bett-Garber, K. L., Champagne, E. T., McClung, A. M., Moldenhauer, K. A., Linscombe, S. D., \& McKenzie, K. S. (2001). Categorizing rice cultivars based on cluster analysis of amylose content, protein content and sensory attributes. Cereal Chem., 78, 551-558.

Greenwood, S. (1998). Consumer trends for the new millennium impact fresh-cut produce. IFPA. http://cook.ucdavis.edu/links/freshcut.pdf 10/8/2002.

Jiang, Y., \& Joyce, D. C. (2002). 1-Methylcyclopropene treatment effects on intact and fresh-cut apple. Journal of Horticultural Science and Biotechnology, 77(1), 19- 21.

Hee, S. N. (2011). Quality characteristics of west african shea butter (Vitellaria paradoxa) and approaches to extend shelflife. Unpublished M.Sc Thesis Graduate School-New B Brunswick Rutgers, The State University of New Jersey.

Honfo, F. G., Hell, K., Akissoe, N., Hinnemann, A., \& Coulibaly, O. (2012). Microbiological and physicochemical characterization of shea butter sold in Benin market. Journal of Stored Products and Postharvest Research, 3(3), 24-29.
Kader, A. A. (Ed). (1992). Postharvest Technology of Horticultural Crops (2nd Edition). UC Publication 3311. University of California, Division of Agriculture and Natural Resources, Oakland, California 94608.

Karen, E. S. A. (2005). Prices and poverty: Agricultural commodities and the position of small scale producers in global economic network. Unpublished M.Sc Thesis, Copenhagen Business School, Denmark.

Kluge, R. A., Nachtigal, J.C., Fachinello, J.C., Bilhalva, A. B. (2002). Fisiologia e manejo pós-colheita de frutas de clima temperado. 2. ed. Pelotas: UFPEL, 163p.

$\mathrm{Li}, \mathrm{H}$., \& Yu, T. (2000). Effect of chitosan on incidence of brown rot, quality and physiological attributes of postharvest peach fruit. Journal of the Science of Food and Agriculture, 81, 269274.

Masters, P., Duka, T., Berris, S., \& Moss, G. (2004). Koalas on Kangaroo Island: from introduction to pest status in less than a century. Wildlife Research, 31, 267-272.

McHugh, T. H., \& Senesi, E. (2000). Apple wraps: A novel method to improve the quality and extend the shelf life of freshcut apples. Journal of Food Science, 65(3), 480-485.

Park, H. J., Chinnan, M. S., \& Shewfelt, R. (1994a). Edible cornzein film coatings to extend storage life of tomatoes. Journal of Food Processing and Preservation, 18, 317-331.

Park, H. J., Chinnan, M. S., \& Shewfelt, R. L. (1994b). Edible coating effects on storage life and quality of tomatoes. Journal of Food Science, 59(3), 568-570.

Risch, S. J., (2002). Impact of product formulation and packaging on shelf life. 2002 Annual Meeting and Food Expo, California 21/04/2018.

Smith, S., Geeson, J., \& Stow, J. (1987). Production of modified atmospheres in deciduous fruits by the use of films and coatings. Horticultural Science. 22(5), 772-776.

Smith, S. M., \& Stow, J. R. (1984). The potential of a sucrose ester coating material for improving the storage and shelf-life qualities of Cox's Orange Pippin apples. Annals of Applied Biology, 104, 383-391. 